\title{
A TRAINING OF SAVING CULTURE FOR OSCAR KINDERGARTEN STUDENT IN SERANG
}

\author{
Dewi Widowati and Fit Yanuar \\ Universitas Sahid, Indonesia \\ dewiwidowati68@gmail.com
}

\begin{abstract}
Saving is an action that can produce positive results. Through saving, someone can prepare funds for the unexpected, or maybe saving activities used as preparation for the needs that have been previously predicted. Saving should be used as a habit. However, not all people have the habit of saving, it needs to be used as a habit in one's life, for that it needs to be educated since childhood so that saving activities become a habit so that in the end the saving culture is never passed until the child becomes an adult. Age 4-6 years is an important age in human life because the imagination and duplication power of children is very high. Therefore it is necessary to education about "saving culture". If a child has been accustomed to setting aside some of his allowance for savings, it will become a habit when growing up. Based on this, the article titled: A training of saving culture for OSCAR Kindergarten Students in Serang, discusses the importance of saving culture starting early. The technique used in this training is Persuasion Communication with contexts tailored to kindergarten students.
\end{abstract}

Keywords: Saving Culture; Persuasion Communication

\section{INTRODUCTION}

Education becomes a very basic thing for someone. Through education also one gets knowledge. At that time the process of applying science and experience was included in the cognitive side of a person, which was then finally reflected through his behavior. Education can not only be obtained formally from school but can also be obtained from home. In other words, a person not only adopts knowledge in school but also imitates what is done, both by parents, home environment, and social environment. Everything that he sees will be absorbed in his mind (cognition), then enters the side of feeling (affection), then only reflected in the side of his behavior (behavior). Furthermore, it becomes a person's mental attitude. Attitude is basically a way of looking at something (Murphy, Murphy, and Newcomb, 1937, p. 889 in Tankard, 2005: 179).

The process of applying a culture of saving for children is as difficult as applying a culture of trash disposal in place or other cultures that parents want to apply to children. Early education is very important because, at an early age, children's imagination and duplication are very high. It is hoped that if knowledge or culture is given at an early age it will be easily accepted and long remembered by children. Therefore, efforts are needed to apply the culture of saving to students through training in class related to the culture of saving. Training can be given by those who care about education.

For this reason, based on the research the writer did in 2019 about the PTKS corporate culture from an internal grant from the University of Sahid Jakarta Batch 7, PTKS has a corporate culture of CIRI (competence; integrity; reliable, innovative). In this case, the basic value of Competence has a value reflecting confidence in one's ability and enthusiasm to increase knowledge, skills, expertise, and mental attitude in order to improve sustainable performance. The basic value of Integrity, reflects a high commitment to each agreement, rules, and regulations as well as applicable laws, through professional loyalty in fighting for the interests of the company. Reliable basic value, reflecting the agreement, speed, and responsiveness in responding to commitments and promises, by synergizing various capabilities to increase customer satisfaction and trust. The basic value of Innovative reflects the willingness to create new ideas and better implementation in improving the quality of processes and work results above the standard. (PT Krakatau Steel's Corporate Culture Handbook, 2009: 9).

Based on this organizational culture, Reliable elements guide the company to pay attention not only to the internal company but also to the company's stakeholders. Give attention to the surrounding community. Including the Oscar Kindergarten, located in the city of Serang. Form attention by providing sponsorships for saving culture training. It is hoped that this training can make students accustomed to seeing direct examples of saving actions in class. Thus this training is a form of community service not only for PTKS but also for writers. 


\section{METHODS}

Material about "saving culture" is delivered very casually, not rigidly. So that the atmosphere of "home" is very pronounced. The condition of the classroom without chairs makes students and teachers have strong personal relationships. The face to face communication method used in the classroom supports the easy absorption of material in students. Including when doing "Saving Culture" training in the classroom.

During the training period from 2 July 2019 until 2 August 2019, significant progress was seen, with many students saving in the classroom coordinated by the teachers. The amount saved is not large, but this has shown a strong motivation to save that is reflected through the behavior (behavior) of students to set aside a little allowance to save. Thus efforts to educate students to save are needed perseverance and patience, especially when having to communicate with students. Persuasion techniques with face-to-face communication (face to face communication) is a powerful enough way to change the behavior of children, who initially never save to be diligent saving. Persuasion is interpreted as a psychological activity to influence the opinions, attitudes, and behavior of a person or people. (Roekomy, 1969: 5). While communication (Hovland, Janis \& Kelly, 1953) is the process of an individual (communicator) passing on stimuli (usually in verbal form) to change the behavior of other individuals (audience/audience). (Miller, 2005: 4). Communication is an exchange of thoughts or ideas. This definition assumes that a thought or idea is successfully exchanged. (Littlejohn, 2009: 5). Thus the training conducted for Oscar Kindergarten students is an exchange of saving cultural messages to students. The thought of "always putting aside" some pocket money is an important theme to be implanted in the minds of kindergarten students Oscar Serang.

\section{Time and Location}

The activity was held on Tuesday 2 July 2019 until 2 August 2019. The location of the activity was at TK \& PAUD Oscar, RW 17, Permata Serang Complex, Sumur Pecung Village, Serang District, Serang City, Banten Province.

\section{Tools and materials}

The tools and materials used in this training are in the form of pictures related to the material presented, namely: a picture of a child who is saving, a piggy bank (a place or container for saving), coins, and stationery relevant to the training.

\section{Method of Implementation}

The method of implementation is done by "face to face communication" or face to face. This allows the writer to know the responses raised by students when explaining the benefits of saving for children. The responses seen were verbal and nonverbal symbols of the students. Because children of kindergarten and early childhood age are still ashamed to express it verbally, the writer looks more at the non-verbal side, namely the act of saving money and the strong desire for discipline to set aside his allowance for savings.

\section{RESULTS AND DISCUSSION}

Kindergarten and PAUD Oscar have 26 students. Consisting of 16 female students and 10 male students. With the number of teachers as many as 5 people, namely 1 Principal and assisted with 4 teachers teaching. Teaching and learning activities prioritize practice, while theories such as reading and writing are carried out very casually. This is done because the character of children aged 4-6 years is more active in moving, not too focused on a material that requires high concentration, so the way of learning and delivery of the material must be conditioned relaxed like a home atmosphere, but still charged with education.

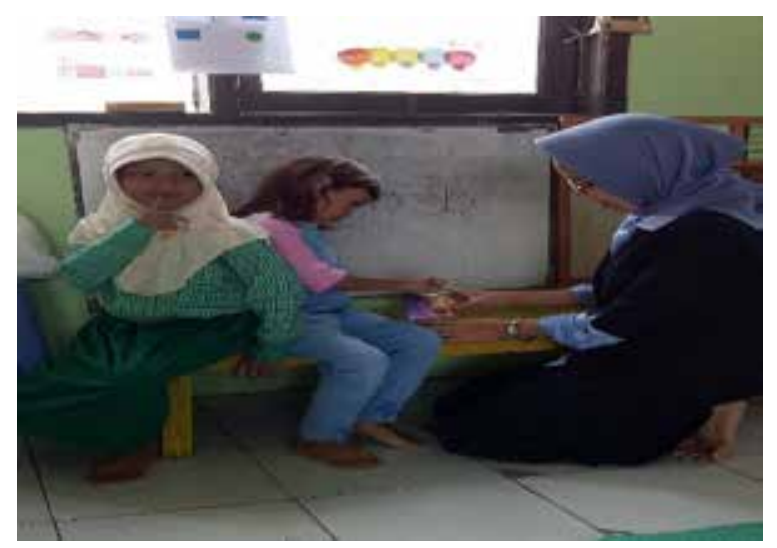

Picture 1.

The training provided for kindergarten children is conditioned relaxed and communication is adapted to the context of children to create a communicative atmosphere. Seen in the picture Two Oscar Kindergarten students who are being trained to put "coins" in a piggy bank. (Private document) 


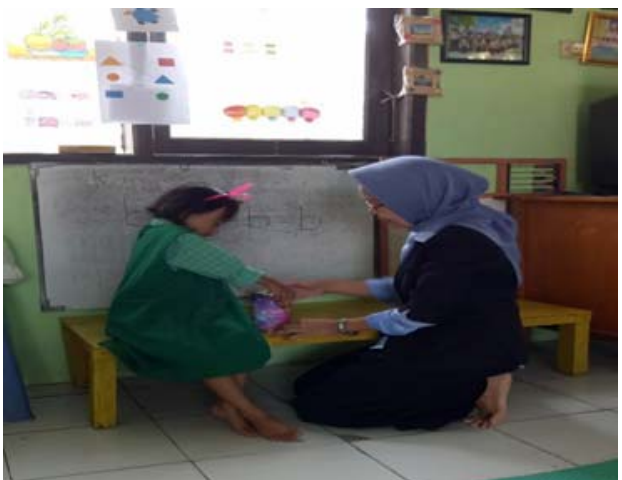

Picture 2.

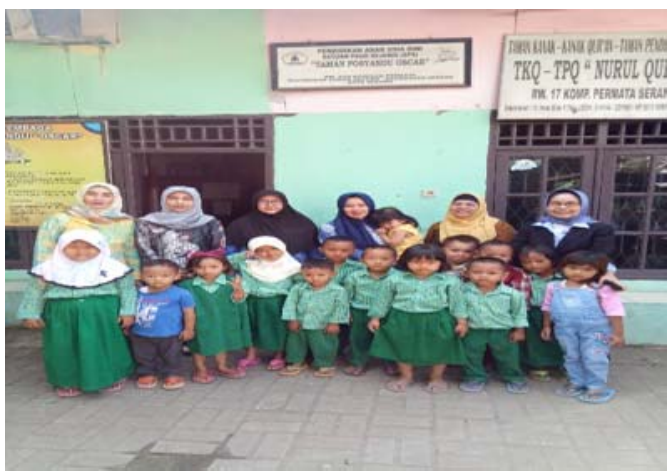

Picture 3.

Picture 2. In the picture, Oscar Kindergarten students enthusiastically took turns putting coins in a piggy bank. Persuasion techniques are an important choice in providing an understanding of the culture of saving, especially aimed at children at the kindergarten level. (Private document).

Picture 3. Oscar kindergarten students and teachers. To educate by teacher is a total devotion to make students not only intelligent, but also has a polite and cultured attitude. (Private document).

\section{CONCLUSION}

1. Attitudes towards saving culture should be familiarized early on so that they become a habit that is firmly planted in children.

2. Education in schools conducted by teachers must also be accompanied by a strong willingness of parents to instill a culture of saving for their children.

3. Face to face communication persuasion becomes one of the choices in instilling a culture of saving in children so that children do not feel forced but are firmly planted in their minds.

\section{REFERENCES}

Littlejohn, S.W. and Karen A. F. (2009). Teori Komunikasi. Jakarta: Salemba Humanika.

Miller, Katherine. (2005). Communication Theories - Perspectives, Processes, and Contexts. Second Edition. New York: McGraw Hill.

Roekomy. (1969). Dasar-dasar Persuasi. Bandung: Yayasan Akademi Penerangan.

Severin, W.J. dan James W.T. (2005). Teori Komunikasi - Sejarah, Metode, dan Terapan di Dalam Media Massa. Jakarta: Kencana Prenada Media Group.

PT Krakatau Steel (Persero) Tbk. (2009). Buku Saku Budaya Perusahaan. Cilegon: PTKS

PT Krakatau Steel (Persero) Tbk. (2011). Enhancing Our Potential To Grow - Meningkatkan Potensi Kami Untuk Tumbuh: Annual Report PTKS. Cilegon: PTKS. 